\title{
Paideusis
}

\section{Philosophy of Education as Mousikē Technē: Footnotes to "Betwixt and Between"}

\section{Deanne Bogdan}

Volume 19, Number 2, 2010

URI: https://id.erudit.org/iderudit/1071918ar

DOI: https://doi.org/10.7202/1071918ar

See table of contents

Publisher(s)

Canadian Philosophy of Education Society

ISSN

0838-4517 (print)

1916-0348 (digital)

Explore this journal

Cite this document

Bogdan, D. (2010). Philosophy of Education as Mousikē Technē: Footnotes to "Betwixt and Between". Paideusis, 19(2), 16-31.

https://doi.org/10.7202/1071918ar viewed online.

https://apropos.erudit.org/en/users/policy-on-use/ 


\title{
Philosophy of Education as Mousikē Technē: Footnotes to "Betwixt and Between"
}

\author{
DEANNE BOGDAN \\ Ontario Institute for Studies in Education, University of Toronto
}

When I was invited to contribute to this special issue, I replied that I had already "done" such a project. ${ }^{1}$ Then I realized that this memoir would be different from my "philosophical autobiography." In this essay, I would offer some personal details, institutional conditions, and preconditions of my academic life. I would also recount some of the nitty-gritty of my zigzag academic career and the process of balancing my musical and philosophical interests as one woman's interdisciplinary approach to practising the discipline of philosophy of education.

\section{Early Dispositions}

Interdisciplinarity invokes the issue of "categories," a common term in philosophical discourse. Some view interdisciplinarity as the often clumsy jumbling up of academic territories that should remain discrete, under the assumption that moving horizontally from one discipline to another comprises a shallow commission of category mistakes (see Fish, 1994). They are probably right, but if done with rigour and respect for disciplinary integrity, interdisciplinary scholarship may be one of the best checks and balances for the "pure" philosopher who wishes to pursue both the practice of, and meta-critical perspective on, "pure" philosophy. I remember as a child being worried about making what to me was a serious category mistake, though, of course, I didn't know the term then. Growing up as an overly devout Roman Catholic in the elementary church school attached to the "Basilica" parish in Hamilton, Ontario, I was influenced by the aesthetics of idealism, enveloped as I was by the soaring architecture of a neo-Gothic cathedral where I sang in the girls chancel choir for daily mass, funerals, weddings, and, once, even an ordination. The cathedral parish had the best adult choir in the city with a massive organ whose reputation was legendary. The choir conductor was a superb organist who had studied the great liturgical musical literature. Each Sunday, I would attend High Mass in the hope that maybe that week I would hear a Palestrina or one of the melodically sublime and harmonically intricate Renaissance masses. Unduly scrupulous and pre-pubescent, I anguished that my religious ardour was more aesthetic

\footnotetext{
1 The Kneller Lecture offers an autobiographical, intellectual history and phenomenology of my own learning and scholarship within higher education in three main areas - philosophy of literature education, women's studies, and philosophy of music education - which parallel the three periods of my academic career. See Deanne Bogdan, "Betwixt and Between: Working Through the Aesthetic in Philosophy of Education." Educational Studies: Journal of the American Educational Studies Association 46.3 (2010): 291-316. This is the published version of the invited George F. Kneller Lecture delivered at the 2008 annual conference of the American Educational Studies Association in Savannah, Georgia.

(C) Copyright 2010. The author, Deanne Bogdan, assigns to Paideusis the right of first publication and educational and non-profit institutions a non-exclusive license to use this document for personal use and in courses of instruction provided that the article is used in full and this copyright statement is reproduced. Any other usage is probibited without the express permission of the author.
} 
than spiritual. To this day, despite now being a "lapsed Catholic," I'm still, Dewey-like, working out the interdependent relationship between religious and aesthetic experience. ${ }^{2}$

If becoming a philosopher entails a love of things academic and a degree of solitude, my elementary school life was a crucible for nurturing the philosophic temper within what shortly will be defined as mousike e techne. For me, as for Italian-American literary theorist Marianna De Marco Torgovnick, "When I was a child, school was . . . a light-filled, wide awake world in which fear did not erupt except on rare occasions. I saw school as a place where I was valued for my intelligence, even though I was female - and this probably had something to do with my absence of fear there."3 I can still feel the anticipatory excitement of my first day of school, fingering the newly-sharpened yellow pencils with $\mathrm{HB}$ leads, and deeply inhaling the smell of bristle board and fat colourful crayons. My identification with my church/school centred around my musical development, which began at age four when the piano I grew up on arrived like a beacon in our home. There has always been something archetypal about my relationship with the piano. I recall at age three racing my sister for "first dibs" at my grandmother's piano on our weekly visits, and then one day realizing that I no longer had to compete with her because she had lost interest. When, as an adult, I asked my mother why she had bought me a piano at such a young age, she replied that she grew tired of my throwing myself on the sidewalk, "going rigid and turning blue" unless, on our many walks in downtown Hamilton, she would take me into the Heintzman \& Co. piano house to try out their latest acquisitions. Coterminous with my eager entry into first grade, piano lessons were begun with Sister Cecile, a gentle nun predisposed to mystical experience, who shepherded me through exams and recitals until high school. Because I could sight-read easily, I was regularly pulled out of class to accompany soloists and dance groups rehearsing for annual Christmas and St. Patrick's Day concerts. I both reveled in, and felt separated by, my difference. I had found my own musical community, which I could enjoy while secure that my schoolwork must have been good enough for me to miss what seemed like huge chunks of class time.

My love of solitude was fuelled by my being sick a lot in grade school. Staying home from school afforded me precious hours of poring over ink drawings (which I loved to copy) and biographies of deep-browed humanists in our home encyclopedia, and the exotic worlds of knowledge they represented. Being sick (but not too sick) allowed me to elaborate beyond reason two major school projects, one on Africa, and the other on Australia. Our grades 7 and 8 classrooms had been provided with lists of "primary sources", which I relished taking advantage of to the point where I actually received a cotton plant from one African supplier! At ten, I wrote letters to, and received personal replies from, the Canadian Broadcasting Corporation producers about their music programmes. Time away from school also allowed me to connect with the larger world of media and books, and to play the piano beyond the limits of those pieces prescribed by conservatory exams, statutory recitals, and Kiwanis competitions. As a former academic, and now celebrated award-winning poet, Ruth Roach Pierson, poignantly writes in "Forms of Rain":

[T] he sick child kept home from school heard sadness in such hushed patter, a sadness with as much Being as colouring books, radio soaps, or the tray her mother brings to her bedside table, bearing tapioca pudding and camomile tea. ${ }^{4}$

\footnotetext{
2 See John Dewey, Art as Experience. 1934. New York: Perigree Books, 1980; Deanne Bogdan, "Musical Spirituality: Reflections on Identity and the Ethics of Embodied Aesthetic Experience in/and the Academy". The Journal of Aesthetic Education 37.2 (2003): 80-98; and "The Shiver/Shimmer Factor: Musical Spirituality, Emotion, and Education,” Philosophy of Music Education Review 18.2 (2010): 111-129.

${ }_{3}^{3}$ Marianna De Marco Torgovnick, Crossing Ocean Parkway. 1994. Chicago and London: The University of Chicago Press. 1996. 41-42.

${ }^{4}$ Ruth Roach Pierson. "Forms of Rain.” Aide-Mémoire. Ottawa: Buschek Books, 2002. 12.
} 
In the 1950s, my parents operated a small corner supermarket where I used to help out after school and on weekends. When business was slow, I always had a library book with me, which I would read as I paced up and down the long wooden floor that separated the produce department from the groceries. If a certain obsessive-compulsive attitude can be associated with the life of an academic philosopher, that could be me. ${ }^{5}$ For several months in middle school, I gobbled up only books about the lives of the great western composers or the Middle Ages, the latter with a distinct focus on the Black Death. At this time, I began collecting 78 RPM records before we owned a phonograph. Every record, movie, and radio programme, along with the intensity of my responses to them, had to be recounted in delicious detail to my mother, who at one point said, "Well, Deanne, you can't spend your life forcing all this down people's throats!" Indeed. Just before graduation from Grade 8 when our teacher/principal asked me what I wanted to be when I grew up, I immediately answered that I would like to be an assembly-line factory worker, because then you would know that you have done something and could forget about it when you got home. The joys and agonies of the converse of that retort have been ubiquitous in my professional life ever since.

\section{Origins of Mousikē Technē: High School, Undergraduate Years, and the M.A.}

While I may have explained in part why I chose to become an academic, the above does not fully account for what drew me to philosophy. My entire secondary school education (1951-1956) was spent in a convent school for girls, where my sister and I were day students at the motherhouse of the School Sisters of Notre Dame in Waterdown, Ontario. In many ways, this time constituted the happiest five years of my life. My sister and I would walk the long block from our home to board the school bus that sped us away with our classmates to a bucolic, rural setting where the massive main building was surrounded by farm animals. With only one class for each grade, we students received a lot of individual attention from the nuns, who were friendly, accessible, and for the most part maternal, but still (to us) exotic. My favorite subjects were Latin, algebra, ${ }^{6}$ and to large extent English, which I enjoyed but found somewhat amorphous at exam time. I remember continually being shaken to my emotional core when Sister Alberta, six feet tall, thin, and ancient, would in a loud, low, measured voice declaim Shakespearean sonnets and dramatic monologues, and then have the class follow her in chorus. This was to me upper case Literature-my first real aesthetic experience outside of music, my response to the latter having to that point epitomized for me the apogee of what living in the arts could mean.

Glimmerings of a questioning attitude surfaced in religion class, where I posed what I thought was a logical contradiction in the biblical dictum, "Love thy neighbour as thyself." My valedictory address to the graduands, an interlacing of concerns about the "Communist threat", the "distorted sense of values" wrought by social change, and the metaphysical importance of each decision made as a moment in time was, despite its conservative bent, existential and interdisciplinary. It concluded with a sonnet (in hindsight, embarrassingly jejune) composed for that event:

The Priceless Moment

From early days of childhood man [sic] will crave

That inner satisfaction of his [sic] soul;

Achievement of an ever-changing goal

Is master of a discontented slave.

\footnotetext{
${ }^{5}$ My doctoral dissertation had so many endnotes that they had to be bound in a separate volume from the body of the text.

${ }^{6}$ Like music, Latin and algebra, ever predictable, never betrayed you if you followed the rules.
} 
Throughout his life, the endless each goes on:

The stone, the toy, the search for wealth and power

Are but a dream-until that fateful hour.

The Hands of Time stand still—-they can be won.

All former false success and idle deeds

Are but a grain of sand-an open door-

In one decision lay the fate of Rome.

Just once he gets a change to plant the seeds.

Was our choice best? I cannot tell you, for

Our priceless moment has as yet to come. (Bogdan, 1955)

From elementary school to the present, music has been the bedrock of my intellectual universe, as both musica practica, through piano and chamber music performance, ${ }^{7}$ and as mousike techne, by way of its association with the humanities and social sciences. I use these terms here to distinguish how I developed my particular strain of interdisciplinarity into becoming a philosopher of education. In high school, I had earned the Solo Performer Certificate in Piano from the Royal Conservatory of Music of Toronto. Because I knew my piano would be buried under the pressure of academics unless studio work "counted," I chose to take the three-year pass BA at the University of Western Ontario, "with the music option," resulting in an added certificate, the Mus.G.Paed, or Graduate in Music Pedagogy. ${ }^{8}$ Here I was introduced to Plato, Aristotle, Aquinas, and had my first taste of aesthetic theory not only through my philosophy electives but also English and French literature. Retrospectively, I realize this was a counterpart to the ancients' concept of mousike techne- - that is, the practice of music as encompassing the fine arts and cultural theory, including philosophy. ${ }^{9}$

In my "Introduction to Philosophy" course, I was particularly enchanted by Plato's Symposium. My very first paper in that class was on a mandatory topic, "What Aristotle Added to Plato." What struck me at the time was the brilliance of the pedagogy in assigning this topic. In order to answer the question, students had to be crystal clear about what each philosopher held regarding metaphysics, ethics, epistemology, and aesthetics, and then determine their inter-relationship. The professor was the same nun, Mother St. Michael, who taught me aesthetics in my final year, $1959 .{ }^{10}$ Hers was the only aesthetics course I could find across campus that was not a warmed-over version of art history. In Mother St. Michael's aesthetics course, I read Henri Bergson, Susanne Langer, George Santayana's The Sense of Beauty, Ortega y Gasset's The Debumanization of Art, and Aristotle's On the Art of Poetry, which was

\footnotetext{
${ }^{7}$ The term musica practica is my neologism for what today we think of as music proper.

8 This degree has since become the model for the undergraduate degree in Music Education at the Faculty of Music, University of Toronto.

${ }_{9}^{9}$ Babette E. Babich. "Mousikē Technē: The Philosophical Practice of Music in Plato, Nietzsche, and Heidegger." Eds. Massimo Verdicchio and Robert Burch, Between Philosophy and Poetry: Writing, Rhythm, History. London and New York: Continuum, 2002. 171, 172.

10 This nun was so avant-garde that she brought Marshall McLuhan to Western in 1957 when he was relatively unknown. We all obediently trudged along the seemingly endless walk from Brescia College to Convocation Hall on the main campus in the dead of winter to hear him. As was the case with the majority of the audience, I had no idea what he was talking about. His lecture was quite brief, and when he asked for questions, there wasn't a single one! My academic confidence was shaken because I had not understood a single word of his presentation. A similar bewildering experience of incomprehension was repeated in the fall of 1962 when I heard Glenn Gould deliver a lecture at McMaster University. What is interesting is that I would later teach McLuhan's work in my York University humanities course and that in 2005 I would embark on a major multi-media project involving my own live piano performance in what was then the Faculty of Information Studies at the University of Toronto (now the Faculty of Information). This comprised a lecture-demonstration that was later published in the University of Toronto' e-journal Media Tropes, in which I show that Gould embodies McLuhan's media theories.
} 
to become one of the cornerstones of my later research and teaching at Ontario Institute for Studies in Education (OISE) at University of Toronto (UT). As an undergraduate, my then largely unconscious practice of mousike e techne swung both ways-from music and philosophy to the other humanities and back. My final paper in the aesthetics course was a justification for Hector Berlioz' Symphonie Fantastique as what musicologist Peter Kivy calls "music alone,"11_ in this case, music that, I argued, could stand on its own as "pure music" apart from the dramatic and elaborate programme for it penned by its composer. Conversely, I was drawn to the philosophical component of my literature courses, especially the French Symboliste poets and the English Romantics-Keats, Coleridge, and Shelley. ${ }^{12}$

In third year, courses in Thomistic philosophy and religious apologetics whetted my appetite for the philosophic life. As well, I actually took a course in the history of philosophy of education; here I was especially struck by the logic of the argument in Hilda Neatby's So Little for the Mind (1953). At the suggestion of my (male) instructor, I wrote my first published paper on a topic that combined music, aesthetics, and philosophy of education-in hindsight, mousike techne..$^{13}$ In those days, I had no recourse to feminist analysis with which to counter my (male) professor's remark that I was the first female student he had ever had who "could write in a straight line." That same year, 1959, I was prompted by Mother St. Michael to enter a student philosophy competition at then Assumption University in Windsor where I won a hardback copy of Jacques Maritain's Creative Intuition in Art and Poetry (1953). Reading my paper at that conference precipitated my first inkling that, despite encouragement from my instructors in the music school to pursue graduate studies in piano, "performance" in academic life was much less threatening. The world of books and print, infinitely consultable, felt more secure than putting yourself out there, psychically naked and vulnerable, on the concert platform where every phrase had to be memorized and perfectly shaped in the existential ether of "the priceless moment."

\section{Life Intervenes}

The kind of mentoring I received as an undergraduate would be continued in graduate school and beyond. But, like many women of my generation, my academic life did not follow the linear (male) model of going straight to the M.A. and Ph.D. Three of our twelve graduates from what was then a very small music school at Western went on to stellar international graduate music schools-Juilliard, London's Royal College of Music, and Salzburg's Mozarteum, respectively; the others headed out to teach high school vocal and/or instrumental music within an educational system that, in stark contrast to today, was welcoming them with open arms. I was still enamored with both musica practica and mousike e techne and I needed time to decide between them at the graduate level. So, rather than applying directly to graduate school, in 1959 I surprised my teachers and classmates by joining the multitude of aspiring teachers who thronged to the provincial sixteen-week long summer school at the Ontario College of Education in Toronto, which purported to prepare us to take up the hundreds of teaching positions that were virtually being thrown at us in the halcyon days of the Robarts explosion in Ontario education. (Over a decade later in the summer school course for my English Specialist's certificate, at the urging of one of my instructors, my final paper became my second publication. ${ }^{14}$ ) I then spent two years from 1959 to 1961 teaching secondary school Latin, English, and music appreciation. I was twenty-one, five years older than my eldest pupil. I loved my students and the predictable structure of

\footnotetext{
${ }^{11}$ See Peter Kivy. Music Alone: Philosophical Reflections on the Purely Musical Experience. Ithaca and London: Cornell University Press, 1990.

12 Shelley's Defence of Poetry featured significantly in my doctoral dissertation years later.

${ }^{13}$ See Deanne Bogdan, "Music as an Expression of a Balanced Aesthetic Education." Review of the Ontario Catholic Teachers' Association (1960): 28-38.

14 See Deanne Bogdan. "A Rhetorical Approach to Teaching Prose Style in Senior English." English Quarterly: Journal of the Canadian Council of Teachers of English (Spring/Summer 1976): 115-128.
} 
the high-school timetable, especially as I was able to teach Latin from the same textbook I had used in Grade 13 just a few years earlier. But I was nostalgic for the academic life, and so spent my evenings and week-ends resuming my piano repertoire and hand-writing letters of inquiry to music graduate schools all over the continent, seeking out programmes that offered the right combination of musica practica and mousikē techne.

My best-laid academic plans were then interrupted by love, marriage, and children. The young man I had dated in high school and by mutual consent from whom I was separated while we each pursued studies at different universities re-entered my life in my first year of teaching. We were married at the end of his penultimate year at the University of Manitoba's School of Architecture, during which time I taught on full-contract as a permanent supply teacher in the Winnipeg school system while learning new piano repertoire at night on a rented upright. It was the coldest winter (1962) in fifty years; we had no car, and I sometimes took four buses to get to my next school, often changing schools at lunchtime. Meanwhile, my husband completed his undergraduate thesis and applied to do his masters at Ivy League graduate schools. The following autumn our daughter was born ten days after he left on full scholarship for Harvard to study the then new discipline of Urban Design. In January 1963, we left Hamilton with our three-month-old infant so that my husband could finish his academic year. I adored living in Cambridge, and spent whatever leisure time I had taking courses in philosophy of personality and philosophy of art offered by The Harvard Wives' (sic) Association, all the while stacking up on my bedside table graduate school calendars of the myriad universities and colleges in the Boston area. My husband had a good job offer, and we had hoped to settle there upon his graduation. I remember carting the baby on my left hip and interviewing for a part-time position at the Cambridge High and Latin School, but family circumstances brought us back to Hamilton for a year before we moved permanently to Toronto in the late summer of 1964.

The push-me-pull-you between musica practica and mousikē techne continued unabated, but the time for making a choice was nigh. It was then that I abandoned "music" for "words" as a profession. For a time, I considered the M.A. in musicology, but something deep inside resisted professionalizing what felt too close to the bone of my core identity. I cannily made a practical decision to develop my philosophical and artistic interests through the discipline of English literature, English being a "teachable subject" in the secondary school as well as a fine art. I thought that the burgeoning discipline of literary criticism could be the golden mean between music and philosophy-in hindsight, my road to following a life of mousike techne-so I took post-degree courses in Chaucer and eighteenthcentury English literature. At the same time, I signed up to do part-time supply teaching in order to garner enough teaching days to qualify for a permanent teaching certificate, with a view to eventually doing an M.A. in English. Supply teaching proved a tricky business for me then. Once the phone call came from the dispatcher, it took three other calls - to the babysitter, nursery school car pool, and back to the dispatcher-before I could agree to fill in for that day. At one school, I was offered a threemonth position, but because I did not want to be away from the children every day, I made a deal with the principal: I would come in three days a week if he would hire a supply teacher for me on the two remaining days, and if he would at the end of the period arrange to have me inspected so that I could finally be awarded the coveted piece of paper. Fortunately, the plan worked out well for everyone.

My stop-gap between the B.A. and M.A. had widened into several years. In 1966, our second daughter was born, and my husband made a life decision to leave his secure position in a large firm to fulfill his dream of opening his own architectural practice. We agreed that his doing so would not scuttle my Plan A, which was to undertake my M.A., part-time though it was. My courses were chosen not just on the basis of interest but to accommodate the respective schedules of the busy lives of family members and to be able to be at home with the children in precious "after school" time. I was able to follow my heart, too: my passion for the lute songs of John Dowland led me to English Renaissance literature, where I fell in love with Sir Philip Sidney's Defense of Poetry, which, unbeknownst to me, was 
germinating to become part of my work in poetic apologetics. ${ }^{15}$ Somehow, we muddled through financially, and by 1972 I emerged a happy master's graduate of York University, not yet countenancing the possibility of ever undertaking the doctorate. During this time, I managed to keep up my musica practica mainly by accompanying one of my York professors who was a baritone. We regularly gave brown bag lunch recitals at York, sometimes performing substantial works like Robert Schumann's song cycle Dichterliebe.

Jobs were scarce, but I was fortunate to be able to choose between two part-time positions, both suited to my predilections for mousikē technē: the first was teaching "Words and Music" at a community college; and the second, as the Senior English Department at the small, boys-only St. Michael's Choir School of Toronto's Cathedral parish. In discussing which position to accept with a colleague who was in favour of the community college, he remarked pointedly, "Surely, Deanne, you don't want the patriarchy, do you?" Well, the fact was that in that instance, yes, I did. I could not resist being part of an academic environment where you could prepare your classes while listening to your students rehearsing Palestrina (and having them sing four-part harmony Christmas carols in our home, my daughters, in glistening wide-eyed wonder as they sat on the stairs), and so the Choir School it was from 1972 to 1978. My girls were six and nine. They willingly set the table and fixed the salad while I pulled out of the freezer one of the meals I'd prepared on the weekend. (Several main courses would habitually go straight from the grocery bag into the oven.).

When I finally confronted head-on the inevitability of my doing the Ph.D., it was my grade 13 class at the Choir School that became the site of the practicum I did with Clive Beck on "Values Education and English in the Secondary School Curriculum". From this experience came my third publication. In it, I employed Aristotelian aesthetic theory to ground our foray into moral education in the artistic integrity of the selected literary works, which I said had to remain primary, with inquiry into their values dimension published as appendices to the literary study. ${ }^{16}$

\section{The Doctorate and the Tenure-Track Position}

While diapering babies in Don Mills in the early 60s, I had read some Jung and continued my interest in Thomistic philosophy mainly through Etienne Gilson's The Arts of the Beautiful (1965) and more Maritain. Through these works, I came to see another fascinating category interrelationship-that between aesthetics and ethics. One quotation from Maritain's The Responsibility of the Artist was to become prophetic not only in my doctoral dissertation, but in my academic life to follow: "No questions are more intricate than those which relate neither to Art alone nor to Ethics alone, but to Art and Ethics at the same time. The philosopher who, at the risk of displeasing everybody, embarks on

15 Sidney's phrase "instruction and delight" became the title of my doctoral dissertation. See Deanne Bogdan. "Instruction and Delight: Northrop Frye and the Educational Value of Literature." Diss. University of Toronto, 1980. A few years later, I became fascinated by Sidney's argument in defense of Plato's banishing the poets from the Republic, and concluded that Sidney held a view of the imagination that went beyond the classicism attributed to him and, rather, prefigured the Romantics' conception of the imagination. In my attempt to place this article with an appropriate journal, I spent a day at the Robarts Library combing the open journal shelves where I found one titled Classical and Modern Literature: A Quarterly. One of my academic treasures is a letter from Plato scholar Morris Henry Partee, who wrote to say that my analysis had changed his thinking on the subject. This kind of outside recognition from an established scholar is invaluable to younger researchers. See Deanne Bogdan. "Sidney's Defense of Plato and the 'Lying' Greek Poets: The Argument from Hypothesis." Classical and Modern Literature: A Quarterly 6.4 (Fall 1986): 43-54.

16 See Deanne Bogdan. "Values and Literary Criticism," Appendix. The Moral Education Project (Year 5) Curriculum and Pedagogy for Reflective Values Education, Final Report, 1976-77. Eds. Clive Beck and Edmund Sullivan. Toronto: OISE Press. This appendix was invited to form part of the Civic Education Project Curriculum Library, CarnegieMellon University. 
such questions must take into account both the dignity and demands of moral life and the dignity and liberty of art and poetry." ${ }^{17} \mathrm{Had}$ I done undergraduate studies at the University of Toronto instead of at Western, I surely would have taken courses from the now legendary Northrop Frye, of whom I knew nothing until one spring morning I ordered his The Educated Imagination: Six Talks for Radio in hard back from the $\mathrm{CBC}$ catalogue. On the first page of this slim volume, Frye poses the very question I had been ruminating about for some time: "What good is the study of literature?" 18 The ethics, aesthetics, and social utility of literary studies — what I later called "the justification problem" - had been born as a promising dissertation topic. For me, Frye's approach to answering this question was a philosophical merger of Platonic issues about the moral status of art and Aristotelian emphasis on the aesthetic integrity of poesis. I had concluded that, as the archetypal apologist for poetry in the tradition of Sidney and Shelley, Frye's conception of "anagogy" as the broadest possible conceptual perspective on literature as "an order of words" 19 was the only valid argument that could answer the problem of Plato's banishment of the poets. Making the case would require an intensive period of reading the entire Frye canon within this anagogic context. In my examination of the banishment, I also encountered one of the most influential sources on my scholarship, Eric A. Havelock's monumental Preface to Plato.

But where best to pursue this blending of literature and philosophy? In 1976, I had been accepted into the English doctoral programmes both at York University and the University of Toronto, as well as OISE in the then Department of History and Philosophy of Education. In my letter of acceptance from the University of Toronto's English department, there was a codicil underlining the fact that earning a Ph.D. in English was no guarantee of a post-secondary job in the field. It went on to say, however, that there was the occasional retirement, and that "people do die"! In discussing my quandary, one of my York professors warned me, "Whatever you do, don't go to the monolith!" By taking eighteenth-century literature, which would fill a gap in my graduate-level English background were I to continue in English, and which would count as an outside minor if I chose philosophy of education at OISE, I bought some time by being dual-enrolled for an entire summer---between the main campus and OISE, located on "the other side of Bloor Street." Because of my interdisciplinary undergraduate degree and my M.A. in English, OISE had wanted me to do another M.A., but having been accepted to the Ph.D. elsewhere, I had declined. The day I went to the department to collect the supporting materials of my application, the then Chair, Ian Winchester, offered to review all my undergraduate and graduate essays from my English courses for "philosophical content," finally offering me direct admission to a three-year residency of twelve half-courses rather than the standard two-year residence of eight half-courses. It sounded good to me! This kind of support and encouragement mitigated a subcutaneous anxiety I had felt about the frankly scary strangeness of a place that offered courses with titles like "Moral Education" and "Hermeneutics." But the departmental offering of "Aesthetics and Education" was a course I immediately warmed to, and so I ended up taking almost all the philosophy courses, including what I called "remedial metaphysics," which was parallel to Frye's graduate course in "remedial metaphor" across the street. The "monolith" proved to be the very opposite of structural rigidity. In fact, I have always thought that the real culture of OISE lies between the floors. For a while, musica practica would remain on the back burner, but mousike techne had come into being as an academic reality through the capaciousness of the OISE philosophy programme, which had apparently deemed my work "real" philosophy. Since then, I have been vitally concerned with the question of what counts as philosophy.

Further mentoring continued when Dwight Boyd invited me to co-author an article that grew out of the first seminar I gave in his moral education course, in which I had undertaken a rhetorical

\footnotetext{
${ }^{17}$ Jacques Maritain. The Responsibility of the Artist. New York: Scribner, 1960. 15-16.

${ }_{18}$ Northrop Frye. The Educated Imagination. Six Talks for Radio. The Massey Lectures, 2nd Series. $1^{\text {st }}$ ed. Toronto: Canadian Broadcasting Corporation, 1963.

${ }^{19}$ Northrop Frye. Anatomy of Criticism: Four Essays. Princeton, NJ: Princeton University Press, 1957. 17.
} 
analysis of Sidney Simon's book on values clarification. ${ }^{20} \mathrm{I}$ had had plans to visit a friend at Harvard who was a Mellon Fellow, and I recall taking the paper, at Dwight's suggestion, to Cambridge in draft form to be reviewed by the legendary Lawrence Kohlberg, who insisted that I sit there watching him as he read it. Intimidated and nervous, I distracted myself by noting the paucity of furniture in his home and the condition of his bookshelves, which were overflowing mainly with the works of Kant and the LPs of Gustav Mahler's symphonies-an apt example, perhaps, of mousikē technee?

My second period of intensive study was precipitated by Ian Winchester who, as editor of Interchange, invited me to write a review article on a book critiquing school textbook censorship. This involved expanding my research on Plato scholarship to get at the crux of how Plato could be simultaneously a gifted artist and censor on the assumption that, if great literature can influence for good, it can also do so for ill. I concluded that Plato's banishment, in effect, invented literary criticism and constituted a defense of poetry by default. ${ }^{21}$

As a full-time graduate student from 1976 to 1980, I was fortunate to have won a Social Science and Humanities Research Council (SSHRC) doctoral fellowship 22 and two postdoctoral fellowships, one at OISE in philosophy of education and another one in English at York. However productive and enjoyable those post-degree years were, I, like so many others, yearned for a tenure-track position. To gain more teaching experience at the university level, I kept my two courses at York ("Literature and Education" and "On Human Communication," focusing on the media theory of Marshall McLuhan). Meanwhile, in 1978, I resigned from my fairly lucrative, pleasurable, part-time job at the Choir School for fear of not being taken seriously as a proper academic. As a late bloomer, I feared my age was going against me, and so was delighted when I was hired to teach "Aesthetics and Education" in OISE's Distance Education Programme. This consisted of six weekends in Wawa, Ontario. Still oblivious to covert sexism, I was nonetheless incensed by the question posed to me as to why I would take on such an "inconvenient" teaching commitment. Apparently, as a middle-class woman married to a professional, I was thought not to need the work.

From 1980 to 1986, the post-secondary job situation was dire. Weekly, I received rejection letters for contract positions. I was, though, invited to teach two graduate courses in my own department. At the instigation of Clive Beck, we developed courses in "Philosophy of Literature and Literature Education" and "Values and Literature in Education", which became mainstays of departmental offerings for several years. It was also Clive who suggested to me that I teach OISE's first course in women's literature and education. While topics in this area were already being developed in other OISE departments, there was no course that focused expressly on the exciting new discipline of feminist literary criticism and pedagogy. Such a course was also deemed an appropriate counterpart in philosophy of education to the immensely popular focus in women's history under the aegis of Ruth Roach Pierson. Preparing for these courses entailed my third intensive period of study in the early and mid-1980s. My foray into women's studies became the turning point in my career, not only professionally but personally and psychologically. Inspired by Susan Laird's fervour about Virginia Woolf's Three Guineas (1938/1966), ${ }^{23}$ I drew heavily on it and on Elaine Showalter's new 1985 collection, The New Feminist Criticism: Essays on Women, Literature, and Theory, which I used as a core text. But my principal learning came directly from my students: the bouleversement ensuing from my

\footnotetext{
20 See Dwight Boyd and Deanne Bogdan. "Something Clarified, Nothing of Value: A Rhetorical Critique of Values Clarification.” Educational Theory 35.3 (1984): 287-300.

${ }^{21}$ See Deanne Bogdan. "Censorship of Literature Texts and Plato's Banishment of the Poets." Interchange: On Education 14.3 (1983): 1-16.

22 The University of Toronto now guarantees four years of full-funding for doctoral students.

${ }^{23}$ In 1988, Susan Laird invited me to be part of a panel on Woolf's Three Guineas, which she had proposed and which was chaired by Ruth Pierson, who also had an abiding interest in this work. The panel was titled, "Is Literary Research on Education Research on Preventing War?" (Conference of American Educational Studies Association. Toronto. November 2-6, 1988).
} 
experience in that course formed the basis for my first paper at the Philosophy of Education Society meeting in San Diego. My account seemed to carry with it a certain interdisciplinary capital and was published in several versions for readers in a variety of disciplines: philosophy of education, English education, women's studies, and aesthetics. ${ }^{24}$

But the tenure-track job continued to elude me. In 1985, I had won an SSHRC General Research grant and was working away at OISE on the promise that sometime in the near future I would obtain at least a one-year contractually-limited-appointment (CLA). Alas, it appeared that no money was available that year! Then out of the blue, I was offered a one-year CLA in York's English department. As I was packing up my office, Ruth Pierson marched into the Chair's office, outraged that OISE would be content to "lose me" to York. Within a week, somehow enough money was found for a nine-month CLA, "with no guarantee," of course, of any work beyond that time. I decided to stay at OISE. Finally, in 1986, two governmental programmes, one provincial and the other federal, were established for faculty renewal. I was fortunate to be successful in both competitions, and finally made it into the tenure-track stream. To this day, I owe my career to Ruth Pierson, Dwight Boyd, Clive Beck and the other philosophy professors who laboured for months to argue for the relevance of what I did and make it an integral component of the department. For this, I also owe a life-long debt of gratitude to the OISE Centre for the Study of Women in Education for their support of my candidacy for the "Young Scholar's Programme," which altered my life forever. Did I feel diminished by getting my job as a result of governmental affirmative action? On the contrary, the enormously competitive nature of both these federal and provincial programmes easily equaled the rigours of the conventional process undertaken by post-secondary search committees. Without those governmental programmes, I would have remained in the same boat that too many young, talented, accomplished, impoverished, and unsecured scholars find themselves in today.

The rest, as we say, is history - a roller coaster ride of a career spanning two decades of being a scholar-researcher and professor of philosophy of education in an increasingly diverse society. I enjoyed the luxury of being able teach what and when I wanted, of having gifted graduate students, and of dove-tailing my courses with my research and scholarship. In major ways, it was the ideal academic situation, but not without often painful conflicts of the culture wars as well.

A fourth period of intensive study came in the 1990s with the advent of the "isms" and their impact on my fields. I did read the major poststructuralists and taught them because the students needed them. The advent of feminism, racism, classism, and post-colonialism as subjects of study have infinitely enriched the post-secondary curriculum in philosophy of education, if indeed philosophy of education even survives within the increasing instrumentalism and corporatization of the universities. In the Kneller Lecture "Betwixt and Between", I set out in some detail the influence on me of the brilliant feminist philosophers of education, especially Jane Roland Martin, Maxine Greene, and Susan Laird, along with how, towards the end of my career, from 1994 and continuing to the present day. I turned toward a final attempt to integrate musica practica with mousike techne in several of what I call my "music papers," which someday, once my current love affair with musica practica burns itself out—or not, I may gather into a book—or not.

\section{Life after OISE/UT}

In retrospect, I realize I was one of the lucky ones. Always of the opinion that my entry into academe was late, not only from the vantage of my age but, collectively, within the context of the history of

\footnotetext{
${ }^{24}$ An elaborated description of this and subsequent bouleversements in my OISE/UT career appear in the sister
} article to this paper, "Betwixt and Between," op. cit. 
women in the academy, ${ }^{25}$ it was only in my position as mentor and counselor to my female graduate students that I came to understand how women's "coming of age in academe" 26 is an ongoing struggle. Yes, I was dedicated and hard-working, but so are, and have been, countless others for whom the "big job" does not happen. As I observe some former students who fortunately are happily ensconced in their chosen academic pursuit, and as I empathize with the egregiously under-employed and underpaid upon whose backs tenure-stream faculty ply their trade, ${ }^{27} \mathrm{I}$ am not sure how far we have come in terms of equity. That the university tacitly accepts this two-tiered condition in the main uncritically under the dubious academically-constructed umbrella of "meritocracy" effaces systemic injustice within an institution that professes its opposite. A second problem, not limited to the academy but certainly an integral part of it, also haunts me, and that is how little societal conditions have changed for women of my daughters' generation in resolving the imbalance between work and home. ${ }^{28}$ Add to this the diminution of print, the scorched earth policy regarding the arts in schools, the demise of philosophy of education as a discipline within educational studies, and the erosion of the humanities generally in our universities, I feel that having been "de-capitated" in 2003 by reason of my birthday under the dictates of a now defunct provincial mandatory retirement policy may have been a blessing in disguise. However, I continue to be involved in academic life as a member of the association of Retired Academics and Librarians of the University of Toronto along with my ongoing relationship with a few academic organizations, especially the International Society for the Philosophy of Music Education. My membership in ISPME has, in turn, spawned my joining a small spin-off group devoted to exploring theoretically, and actively advocating for, recognition of the essential role of spirituality in music education. In June 2010, I attended the First International Conference of Spirituality in Music Education held in Birmingham, England.

Regarding my family, my husband continues in his private architectural practice, with his perennial promise "to ease himself out." But as an artist for whom work has invariably been play in the best sense, he will always be involved in creating three-dimensional aesthetic space in some way. If the cliché that architecture is frozen music has any validity, I like to think that we have actualized it in living our lives, through his intense love of music despite his lack of formal musical training, and my being able to appreciate some aspects of good design despite my not being able to read a blueprint to save my life. Aesthetic theory and experience is the glue that cements our mutual understanding about our respective artistic passions. Our daughters had musical training but professionally have pursued their gifts for the visual arts inherited from their father. Our elder daughter did become an academic, and teaches decorative arts and history of design in London, England; her younger sister works as an architect with the Ontario Ministry of Health. As mothers who have followed their own professional dreams, they struggle with the split-brain between home and work even though their partners do all the cooking. If I were to have a second academic career, I would undertake intensive study of this crucial social problem, inflected as it is with issues of race, gender, and class. Meanwhile, I am a contented,

\footnotetext{
${ }^{25}$ For a different take on the meaning of "late," see Jane Miller. "Late." Crasy Age: Thoughts on Being Old. London: Virago Press, 2010. 156-171.

26 See Jane Roland Martin. Coming of Age in Academe. New York: Routledge, 2000; and Susan Laird, Lucy Townsend, and Susan Franzosa. Society for Educating Women. n.d. Web. 8 June 2010. $<$ http://www.educatingwomen.net>

${ }^{27}$ In a recent issue of the MLA Newsletter, however, the editor pointedly takes up this issue, concluding her column by saying that "there's one fundamental question I want to leave you with, one I ask myself every day. Can't we as a profession agree to do whatever is necessary so that all academic positions offer adequate compensation, job security, and professional dignity?" Rosemary G. Feal. "Editor's Column: Contingent Faculty Members: More Alike than Different?" MLA Newsletter 42.2 (2010): 6. For references from the MLA Newsletter, see "MLA References on Equity in Academe" at the end of this article.

${ }^{28}$ For a valuable website about the home/work problem in academe as it relates to women and graduate studies, see Rosmarie Emanuele. "Mama PhD: Mothers Attempting to Balance Parenthood and Academics." BlogU. 20 May 2010. Web. 28 May 2010. <http://www.insidehighered.com/blogs/mama phd>
} 
joyful grandmother of two granddaughters, one in Toronto and one in London-of-the-world. Blessed with the privilege of time and material resources (not available to all) to take them to concerts and to participate in various ways in their musical lives, I am keenly involved in all aspects of their development, but it is the central role of the arts that continues to be my most vital interest in their education.

Since retirement, my academic activity has consisted of several conference papers, five published articles, including the Kneller Lecture ("Betwixt and Between") and the multi-media piece on Marshall McLuhan and Glenn Gould. My most recent article on spirituality and the philosophy of music education uses Richard Shusterman's pragmatist aesthetics and Jungian analyst Marion Woodman's conceptions of "cellular resonance" and "bodysoul" in working to dissolve the Platonic false dichotomy between spirit and matter. ${ }^{29}$ In 2007, I was one of thirty-two invited international participants to gather in the Berkshires to redraw the map of music education through Tanglewood II, which in "Betwixt and Between" I describe as mousikē techne "writ large." 30 I have also fulfilled my dream of returning to musica practica as a "serious practiser" of the piano, my primary discipline and first love. It is wonderful to be a student again, in both private lessons and as a member of a performance master class conducted by my coach/teacher Boyanna Toyich of the University of Toronto's Faculty of Music through their Community Outreach Programme. In 2008, I participated in the inaugural twoweek summer conference for musical performers given jointly by the University of Toronto's Faculty of Music under Toyich and the Universita Populare of Rome. Inspired by Toyich's class, six of us seniors formed the Master Class Players, who perform free hour-long concerts at local libraries and hospitals as well as at fundraisers and charitable events. Being out there on a concert stage no longer feels quite as frightening as it once did. My current piano project challenges my long-standing prejudice against "programme music." While at Tanglewood II, I first encountered Leoš Janáček's "Sonata. 1.X. 1905, "From the Street." This work was composed in commemoration of the death of a twenty-yearold student who succumbed to stab wounds suffered in a peaceful protest march for academic freedom that took place in Brno, Czechoslovakia, October 1, 1905. I would still argue, though, as I did with the Berlioz in 1959, that this sonata, while it is a powerful extra-musical statement, transcends the bounds of anything that can be said about it as mousike techne, that it reaches deep into the human heart on its own terms as musica practica.

Coming full circle, recently Ruth Pierson and I have reconnected through the arts by performing joint poetry readings/piano recitals within the spirit of both musica practica and mousikē technēe. Our collaboration has made my mousike techne more palpable and much less a case of betwixt and between the two sides of my corpus collosum, as it has been for the most part throughout my academic career. In the past, my ongoing hemispheric conflict was a kind of "dissociation of sensibility", ${ }^{31}$ which I trust, in

${ }^{29}$ Deanne Bogdan. "Music, McLuhan, Modality: Musical Experience from 'Extreme Occasion' to 'Alchemy'." MediaTropes 1.1 (2008): 71-101. See also Deanne Bogdan. "The Shiver-Shimmer Factor." op. cit., and Tina Stromsted. "Cellular Resonance and the Sacred Feminine: Marion Woodman's Story." Spring Journal 72: A Journal of Archetype and Culture: Body and Soul, Honoring Marion Woodman 26 (2005): 1-30.

${ }^{30}$ Deanne Bogdan, "Betwixt and Between," op. cit., 307.

${ }^{31}$ In "The Metaphysical Poets", T.S. Eliot observes that the English dramatists of the sixteenth century and their successors, the poets of the seventeenth century, "possessed a mechanism of sensibility which could devour any kind of experience." But ever since Milton and Dryden mastered the art of integrating sensibility, language and feeling became divorced in the history of English literature. In general, "while the language became more refined, the feeling became more crude," and there grew up either sentimentality or cerebration. In the nineteenth century, Eliot sees "traces of a struggle toward unification of sensibility. But Keats and Shelley died, and Tennyson and Browning ruminated." See T.S. Eliot. "The Metaphysical Poets.” Eds. Frank Kermode. Selected Prose of T.S. Eliot. London: Faber and Faber, 1975. 64-65. Frye modified Eliot's concept to indicate the imbalance of thought and emotion that characterizes most aesthetic responses, cautioning that, while respondents may hope for the integration of sensibility that comes from the fusion of intellect and emotion typified by the union of subject and object, they should not expect it. I associate aesthetic integration of sensibility with what Longinus described as 
time, will dissipate. The opportunity to write this memoir, to knit up the various remembereds and forgottens of my early and later predispositions, mentors, and influences in philosophy of education has contributed to this process of reintegrating my sensibility, and I thank the editors and readers for what for me has been an aesthetic experience.

\section{References}

Aristotle. "On the Art of Poetry." Aristotle, Horace, Longinus: Classical Literary Criticism. Ed. T. S. Dorsch. Harmondsworth, England: Penguin, 1965.

Babich, Babette E. "Mousikē Technē Between Philosophy and Poetry: Writing, Rhythm, History. Eds Massimo Verdicchio and Robert Burch. London and New York: Continuum, 2002. 171-180.

Bogdan, Deanne. “The Priceless Moment." Unpublished Poem. 1955.

Bogdan, Deanne. "Music as an Expression of a Balanced Aesthetic Education." Review of the Ontario Catholic Teachers' Association (March 1960): 28-38.

Bogdan, Deanne. "A Rhetorical Approach to Teaching Prose Style in Senior English.” English Quarterly: Journal of the Canadian Council of Teachers of English (Spring/Summer 1976): 115-128.

Bogdan, Deanne. "Values and Literary Criticism." The Moral Education Project (Year 5) Curriculum and Pedagogy for Reflective V alues Education, Final Report, 1976-77. Eds. Clive Beck and Edmund Sullivan. Toronto: OISE Press, 1976.

Bogdan, Deanne. "Instruction and Delight: Northrop Frye and the Educational Value of Literature." Diss. University of Toronto, 1980.

Bogdan, Deanne. "Censorship of Literature Texts and Plato's Banishment of the Poets." Interchange: On Education 14.3 (1983): 1-16.

Bogdan, Deanne. "Sidney's Defence of Plato and the 'Lying' Greek Poets: The Argument from Hypothesis." Classical and Modern Literature: A Quarterly 6.4 (1986): 43-54.

Bogdan, Deanne. "Is Literary Research on Education Research on Preventing War?" Conference Paper - American Educational Studies Association (Symposium on the 50th Anniversary of Virginia Woolf's Three Guineas). Toronto, 1988.

Bogdan, Deanne. "Judy and Her Sisters: Censorship and the Poetics of Need." Plenary Session, Proceedings of the Forty-Fourth Annual Meeting of the Philosophy of Education Society, San Diego, CA, March 25-28, 1988. Ed James Giarelli. Normal, IL: University of Illinois Press, 1989. 66-77.

Bogdan, Deanne. "Censorship, Identification, and the Poetics of Need." The Right to Literacy. Eds. Andrea Lunsford, Helene Moglen, and James Slevin. New York: Modern Language Association of America, 1990. 128-147.

Bogdan, Deanne. Re-educating the Imagination: Towards a Poetics, Politics, and Pedagogy of Literary Engagement. Portsmouth, NH: Boynton-Cook-Heinemann, 1992.

Bogdan, Deanne. "Musical Spirituality: Reflections on Identity and the Ethics of Embodied Aesthetic Experience in/and the Academy." The Journal of Aesthetic Education 37.2 (2003): 80-98.

ecstasis, "the true sublime ... proud exaltation and ... sense of vaunting joy" that makes us feel "as though we had ourselves produced" what we have experienced. Longinus. "On the Sublime." Ed. T.S. Dorsch,.Aristotle, Horace, Longinus: Classical Literary Criticism. Harmondsworth, England: Penguin, 1965. 107. For an elaboration of this argument in Frye, see Deanne Bogdan, E. James Cunningham, and Hilary E. Davis. "Reintegrating Sensibility: Situated Knowledges and Embodied Readers." New Literary History: A Journal of Theory and Interpretation, Issue on Pbilosophical and Rhetorical Inquiries 31.3 (2000): 477-507. The concept "situated knowledges" is drawn from Donna Haraway's landmark essay, "Situated Knowledges: The Science Question in Feminism and the Privilege of Partial Perspective.” Feminist Studies 14.3 (1988): 575-600. 
Bogdan, Deanne. "Music, McLuhan, Modality: Musical Experience from 'Extreme Occasion' to 'Alchemy." MediaTropes 1.1 (2008): 71-101. Web. 18 May 2008. $<$ http://www.mediatropes.com $>$

Bogdan, Deanne. "Betwixt and Between: Working Through the Aesthetic in Philosophy of Education." The 2008 George F. Kneller Lecture. Educational Studies: A Journal of the American Educational Studies Association 46.3 (2010): 291-316.

Bogdan, Deanne. "The Shiver/Shimmer Factor: Musical Spirituality, Emotion, and Education." Philosophy of Music Education Review 18.2 (2010): 111-129.

Bogdan, Deanne. E. James Cunningham, and Hilary E. Davis. "Reintegrating Sensibility: Situated Knowledges and Embodied Readers." New Literary History: A Journal of Theory and Interpretation, Issue on Philosophical and Rhetorical Inquiries 31.3 (2000): 477-507.

Boyd, Dwight, and Deanne Bogdan. "Something Clarified, Nothing of Value: A Rhetorical Critique of Values Clarification.” Educational Theory 35.3 (1984): 287-300.

De Marco Torgovnick, Marianna. Crossing Ocean Parkway. 1994. Chicago and London: The University of Chicago Press, 1996.

Dewey, John. Art as Experience. 1934. New York: Perigree Books,1980.

Eliot, T.S. “The Metaphysical Poets." Selected Prose of T.S. Eliot. Ed. Frank Kermode. London: Faber and Faber, 1975. 59-67

Emanuele, Rosmarie. "Mama PhD: Mothers Attempting to Balance Parenthood and Academics." BlogU. 20 May 2011. Web. 28 May 2010. < http://www.insidehighered.com/blogs/mama phd.>

Feal, Rosemary G. "Contingent Faculty Members: More Alike than Different?" MLA Newsletter 42.2 (2010): 5-6.

Fish, Stanley. "Being Interdisciplinary Is So Very Hard to Do." There's No Such Thing as Free Speech: And It's a Good Thing, Too. New York and Oxford: Oxford University Press, 1994. 231-242.

Frye, Northrop. Anatomy of Criticism: Four Essays. Princeton, NJ: Princeton University Press, 1957.

Frye, Northrop. The Educated Imagination. Six Talks for Radio. The Massey Lectures, $2^{\text {nd }}$ Series. $1^{\text {st }}$ Edition Toronto: Publications of the Canadian Broadcasting Corporation, 1963.

Gasset, Ortega J.. The Dehumanization of Art and Other Essays on Art, Culture, and Literature. Garden City, New York: Doubleday Anchor Books, 1956.

Gilson, Etienne. The Arts of the Beautiful. New York: Scribner, 1965.

Haraway, Donna. "Situated Knowledges: The Science Question in Feminism and the Privilege of Partial Perspective." Feminist Studies 14.3 (1988): 575-600.

Havelock, Eric. A. A History of the Greek Mind, Volume One: Preface to Plato. Cambridge, MA: Belknap Press of Harvard University Press, 1963.

Kivy, Peter. Music Alone: Philosophical Reflections on the Purely Musical Experience. Ithaca and London: Cornell University Press, 1990.

Langer, Susanne K. Philosophy in a New Key: A Study in the Symbolism of Reason, Rite, and Art. 3rd ed. 1942. Cambridge, MA: Harvard University Press, 1982.

Langer, Susanne K. Feeling and Form: A Theory of Art. New York: Scribner, 1953.

Longinus. "On the Sublime." Aristotle, Horace, Longinus: Classical Literary Criticism. Ed. T.S. Dorsch. Harmondsworth, England: Penguin, 1965. 99-157.

Maritain, Jacques. Creative Intuition in Art and Poetry. New York: Pantheon Books, 1953.

Maritain, Jacques. The Responsibility of the Artist. New York: Scribner, 1960.

Martin, Jane Roland. Coming of Age in Academe. New York: Routledge, 2000.

McLuhan, Marshall. Understanding Media: The Extensions of Man. $2^{\text {nd }}$ ed. New York: The New American Library, 1966.

Miller, Jane. "Late." Crazy Age: Thoughts on Being Old. London: Virago Press, 2010. 156-171

Neatby, Hilda. So Little for the Mind. Toronto: Clark, Irwin, 1953. 
Plato. "Symposium" and "Republic". Plato: The Collected Dialogues, Including the Letters. Trans. Lane Cooper. Eds. Edith Hamilton and Huntington Cairns. Princeton, NJ: Princeton University Press, 1961. 526844.

Pierson, Ruth Roach. Aide-Mémoire. Ottawa: Buschek Books, 2002.

Santayana, George. The Sense of Beauty. Eds. William G. Holzberger and Herman J. Saatkamp. Cambridge, MA: MIT Press, 1988.

Shelley, Percy Bysshe. "A Defence of Poetry." A Defense of Poetry/The Four Ages of Poetry: Shelley and Peacock. Ed. John E. Jordon. Indianapolis and New York: The Bobbs-Merrill Company, Inc., 1821/1965. 2380.

Showalter, Elaine. The New Feminist Criticism: Essays on Women, Literature, and Theory. New York: Pantheon, 1985.

Shusterman, Richard. Pragmatist Aesthetics: Living Beauty, Rethinking Art. Cambridge, MA: Blackwell, 1992.

Sidney, Sir Philip. A Defense of Poetry. Ed. J. A. Van Dorsten. London: Oxford University Press, 1966.

Stromsted, Tina. "Cellular Resonance and the Sacred Feminine: Marion Woodman's Story." Spring Journal 72: A Journal of Archetype and Culture: Body and Soul, Honoring Marion Woodman 26 (2005): 130.

Woolf, Virginia. Three Guineas. 1938. New York: Harcourt, 1966.

\section{Modern Language Association (MLA) References on Equity in Academe}

Coalition on the Academic Workforce. "One Faculty Serving All Students: An Issue Brief by the Coalition on the Academic Workforce." Coalition on the Academic Workforce, February 2010. Web. 30 March 2010.

< http://www.academicworkforce.org/CAW_Issue_Brief_Feb_2010.pdf>

Laurence, David. "Demography of the Faculty: A Statistical Portrait of English and Foreign Languages. Modern Language Association.” Modern Language Association, 10 December 2008. Web. 29 Mar. 2010.

$<$ http://www.mla.org/pdf/demography_fac2.pdf>

Modern Language Association Executive Council. "MLA Issue Brief: The Academic Workforce." Modern Language Association, 2009. Web. 30 March 2010.

$<$ http://www.mla.org/awak_issue_brief_pdf >

Modern Language Association. "Education in the Balance: A Report on the Academic Workforce in English.” Modern Language Association, 10 December 2008. Web. 29 March 2010. $<$ http://www.mla.org/report_aw $>$

National Center for Education Statistics. "2004 National Study of Postsecondary Faculty: Report on Faculty and Instructional Staff in Fall 2003." National Center for Educational Statistics, 2005. Web. 29 March 2010. < http://nces.ed.gov/pubsearch/pubsinfo.asp?pubid=2005172>

United Academics. "A National Survey of Part-Time/Adjunct Faculty." American Academic 2 (March 2010). Web. 30 March. 2010. <http://www.aft.org/pdfs/highered/aa_partimefaculty0310.pdf>

\section{Works That Have Significantly Influenced My Thinking}

Aristotle. "On the Art of Poetry." Aristotle, Horace, Longinus: Classical Literary Criticism. Ed. T. S. Dorsch. Harmondsworth, England: Penguin, 1965. 31-75.

Bartky, Sandra Lee. Femininity and Domination: Studies in the Phenomenology of Oppression. New York: Routledge, 1990.

Frye, Northrop. Anatomy of Criticism: Four Essays. Princeton, NJ: Princeton University Press, 1957. 
Frye, Northrop. The Educated Imagination. Six Talks for Radio. The Massey Lectures, $2^{\text {nd }}$ Series. $1^{\text {st }}$ ed. Toronto: Canadian Broadcasting Corporation, 1963.

Greene, Maxine. Releasing the Imagination: Essays on Education, the Arts, and Social Change. San Francisco, CA: Jossey-Bass, 1995.

Haraway, Donna. "Situated Knowledges: The Science Question in Feminism and the Privilege of Partial Perspective." Feminist Studies 14.3 (1988): 575-600.

Havelock, Eric. A. A History of the Greek Mind, Volume One: Preface to Plato. Cambridge, MA: Belknap Press of Harvard University Press, 1963.

Laird, Susan. Mary Wollstonecraft: Philosophical Mother of Coeducation. New York: Continuum, 2008.

Maritain, Jacques. The Responsibility of the Artist. New York: Scribner, 1960.

Martin, Jane Roland. Reclaiming a Conversation: The Ideal of the Educated Woman. New Haven, CT: Yale University Press, 1985.

Miller, Jane. Seductions: Studies in Reading and Culture. Cambridge, MA: Harvard University Press, 1994.

Morrison, Toni. Whiteness and the Literary Imagination. Cambridge, MA: Harvard University Press, 1992.

Nussbaum, Martha C. Love's Knowledge: Essays on Philosophy and Literature. Oxford and New York: Oxford University Press, 1990.

Plato. "Symposium" and "Republic". Plato: The Collected Dialogues, Including the Letters. Trans. Lane Cooper. Eds. Edith Hamilton and Huntington Cairns. Princeton, NJ: Princeton University Press, 1961. 526844.

Showalter, Elaine. The New Feminist Criticism: Essays on Women, Literature, and Theory. New York: Pantheon, 1985.

Shusterman, Richard. Pragmatist Aesthetics: Living Beauty, Rethinking Art. Cambridge, MA: Blackwell, 1992.

Sidney, Sir Philip. A Defense of Poetry. Ed. J.A. Van Dorsten. London: Oxford University Press, 1966.

Woodman, Marion. The Pregnant Virgin: A Process of Psychological Transformation. Toronto: Inner City Books, 1985.

Woolf, Virginia. Three Guineas. 1938. New York: Harcourt, 1966. 